\title{
Cattle treading effects on sediment loss and water infiltration
}

\author{
J. R. RUSSELL, K. BETTERIDGE, D. A. COSTALL, AND A. D. MACKAY
}

Authors are professor, Department of Animal Science, Iowa State University, Ames, Iowa 50011; and scientist, research technician, and scientist, Grasslands Division, AgResearch, Private Bag 11008, Palmerston North, New Zealand.

\begin{abstract}
To quantify effects of forage canopy properties, soil surface relief, and hill slope on the hydrologic properties of the soil in a New Zealand hill land pasture, duplicate plots $(15 \times 3 \mathrm{~m})$ with 3 canopy heights $(6,20$, and $47 \mathrm{~mm})$ were trodden with 0,4 , or 8 mature cows for $40 \mathrm{~min}$ on a moderate $\left(\mathbf{1 5}^{-18^{\circ}}\right)$ slope (Trial 1), and similar plots with the low and high canopy heights were trodden by 8 mature cows for 40 min on gentle $\left(8-14^{\circ}\right)$, moderate $\left(15-18^{\circ}\right)$, or moderately steep $\left(20-25^{\circ}\right)$ slopes (Trial 2$)$. Pre- and post-treading measurements included canopy heights; bare soil proportions; soil moisture contents; hoof prints and skids; roughness coefficients, surface water detention storage volumes, and soil clump volumes with a 38-pin contometer; and water infiltration and sediment loss by rainfall simulation. In Trial 1, increasing canopy height resulted in lower $(P<0.01)$ proportions of bare ground, roughness coefficients, soil clump volumes, and sediment losses. Increasing treading damage resulted in higher $(\mathbf{P}$ $<0.05)$ post-treading roughness coefficients, proportions of bare ground, hoof print and skid densities, surface water detention volumes, and soil clump volumes. In Trial 2, soil hydrologic properties did not differ between canopy height or hill slope treatments. In the two trials, water infiltration rate was significantly related to the roughness coefficient $\left(r^{2}=0.31\right)$ and the number of hoof prints $\left(r^{2}=0.26\right)$. Results imply that a 20 -mm canopy height of the forage species common on a New Zealand hill land pasture is adequate to minimize the effects of a short-term treading event on soil water infiltration rate and sediment loss.
\end{abstract}

Key Words: Hoof damage, canopy, erosion, surface roughness, topography

Damage to vegetation and soils by hoof trampling occurs in pastures grazed at high stock densities, particularly when heavyweight cattle graze on moist soils (Sheath and Boom 1997, Betteridge et al. 1999). The loss of vegetative and litter cover caused by grazing at high stock densities (Warren et al. 1986a, 1986b, Thurow et al. 1988b) allows direct impact of raindrops on soils (Lal and Elliot 1994). Increased soil bulk density resulting from machinery traffic (Voorhies et al. 1989) or trampling

Journal paper no. J-18267 of the Iowa Agr and Home Econ. Exp. Sta., Ames, Iowa, project no. 3237 .

The senior author was funded in part by a fellowship under the OECD Co-operative Research Program: Biological Resource Management for Sustainable Agriculture Systems. The authors wish to thank Mr. Bill Carlson for supplying rainfall simulators and assisting in rainfall simulation measurements, Mr. Robert Fletcher for providing statistical advice, and Mr. Andrew Graham and Mr. John Napier for providing field assistance.

Manuscript accepted 22 May 2000

\section{Resumen}

Para cuantificar los efectos de las propiedades de la copa del forraje, el relieve de la superficie del suelo y la pendiente de la montaña en la propiedades hidrológica del suelo, se establecieron en un potrero de montaña de Nueva Zelanda parcelas ( 15 x 3 m) duplicadas con tres alturas de copa del forraje $(6,40$ y $47 \mathrm{~mm})$ las cuales se pisotearon durante 40 minutos con 0,4 y 8 vacas maduras en una pendiente moderada $\left(15-18^{\circ}\right)$ (enasyo1). También se establecieron parcelas similares en terrenos con una pendiente suave $\left(8-14^{\circ}\right)$, moderada $\left(15-18^{\circ}\right)$ y moderadamente pronunciada $\left(20-25^{\circ}\right)$ con alturas de copa baja y alta las cuales fueron pisoteadas por 8 vacas maduras durante 40 minutos (ensayo 2). Las variables medidas antes y después de pisotear las parcelas incluyeron: altura de la copa, proporciones de suelo desnudo, contenido de humedad del suelo, huellas de pezuña y resbalones, coeficientes de rugosidad, volúmenes de detención y almacenamiento de agua superficial y volúmenes suelo pisado, medido con un medidor de contorno de 30 agujas, la infiltración de agua y perdida de sedimento determinados mediante simulación de lluvia. En el ensayo 1, el incremento de la altura de la copa resulto en menores $(P<0.01)$ proporciones de suelo desnudo, coeficientes de rugosidad, volúmenes de suelo pisado y perdidas de sedimento. El incremento en el daño por pisoteo resulto en que después del pisoteo se tuvieran mayores $(P<0.05)$ coeficientes de rugosidad, proporciones de suelo desnudo, densidad de huellas de pezuña y resbalones, volúmenes de detención de agua superficial y volúmenes de suelos pisoteado. En el ensayo 2, las propiedades hipológicas del suelo no defirieron entre tratamientos de altura de copa o pendiente de la montaña. En los dos ensayos, la tasa de infiltración del agua se relacionó significativamente con los coeficientes de rugosidad del terreno $\left(r^{2}=0.31\right)$ y el número de huellas de pezuña $\left(r^{2}=0.26\right)$. Los resultados indican que una altura de copa de $20 \mathrm{~mm}$ de las especies forrajeras comunes en los pastizales de montaña de Nueva Zelanda es adecuada para minimizar los efectos a corto plazo del pisoteo sobre la infiltración del agua en el suelo y la perdida de sedimento.

(Warren et al. 1986c, 1986d) of moist soils reduces water infiltration into the soil. The combination of these effects increases surface water flow and sediment loss (Thurow et al. 1986, 1988a, Warren et al. 1986a, 1986d).

In addition to reducing soil surface cover and increasing soil bulk density, hoof damage increases surface roughness (Betteridge et al. 1999). Increased surface roughness may reduce water runoff and sediment loss by lowering kinetic energy of surface water and acting as a trap for detached soil particles (Warren et al. 1986a). On moderate and steep slopes, however, the increased kinetic energy in downhill water flow may exceed the 
mitigating effects of shortened slope length and greater trapping capacity of damaged surfaces and, thereby, increase soil erosion.

The objectives of the present experiment were: (1) to quantify the interactive effects of canopy cover, forage density and canopy height, surface roughness, and hill slope on water infiltration and sediment loss on a moist soil in a New Zealand hill country pasture; and (2) to establish the relationships between physical measurements of soil topography, surface configuration, vegetative cover, and forage density on surface water runoff and sediment loss.

These hill country pastures are commonly grazed by sheep and cattle together, or in some integrated rotation, with canopies being reduced from 150 250 mm to $25 \sim 40 \mathrm{~mm}$ during long winter-spring rotational grazings in which stock remain in a small area of pasture for 24 48 hours.

\section{Materials and Methods}

\section{Study Area}

The study was conducted at the AgResearch 'Ballantrae' Hill Country Research Station in southern Hawkes Bay, New Zealand $\left(175^{\circ} 50^{\prime} \mathrm{E}, 40^{\circ} 19^{\prime} \mathrm{S}\right)$ at an elevation of approximately $170 \mathrm{~m}$. Soils are Kumeroa hill soils classified as Typic Dystrochrepts related to yellow brown earth and yellow grey earth intergrades. These soils are primarily fine sandy loams with a clay content of 18 to $20 \%$, low organic matter content, and low macroporosity formed on a shallow layer of tertiary sandstone, siltstone or mudstone resulting in poor drainage. The study was conducted on an easterly aspect at slopes of 8 to $25^{\circ}$. Normal annual precipitation at the location is $1,200 \mathrm{~mm}$ of which $55 \%$ falls during winter and spring. Normal mean temperatures are 16.0 and $7.2^{\circ} \mathrm{C}$ during summer and winter (Lambert et al. 1983) and, therefore, there is little snow or freezing. Plant composition of the site was $25.7 \%$ Agrostis tenuis Sibth., 16.4\% Lolium spp., $14.6 \%$ Cynosurus cristorus L., $14.1 \%$ Anthoxanthum odoratum L., 12.7\% Holcus lanatus L., $6.5 \%$ Trifolium repens L., $1.5 \%$ Poa spp., and $8.5 \%$ other species (Lambrechtsen 1972). Mean pasture density, determined from twentyseven, $78 \mathrm{~cm}^{2}$ cores, was 22,500 grass tillers $\mathrm{m}^{-2}$ and 1,600 legume tillers $\mathrm{m}^{-2}$; being typical of fine-leaved sheep-grazed pastures in New Zealand. Cattle-only pastures typically have tiller densities ranging between 6000 to 1,000 tiller $\mathrm{m}^{2}$. The pastures had been grazed by sheep for the pre- ceding 3 years and had been fertilized with phosphorus at $12.5 \mathrm{~kg} \mathrm{ha}^{-1}$ as rock phosphate. Mean soil moisture was $416 \mathrm{~g} \mathrm{~kg}^{-1}$.

\section{Design and Treatments}

Two blocks containing three, 15 x 9-m plots were fenced to exclude sheep in September 1997. Plots were randomly assigned to 1 of 3 treading treatments; control, moderate, and severe. Each plot was subdivided into three, 15 x 3-m subplots. Subplots were randomly assigned to 1 of 3 canopy height treatments; denuded, $20 \mathrm{~mm}$ or $47 \mathrm{~mm}$. Subplots with the denuded treatment were sprayed with glyphosate (isopropylamine salt of $\mathrm{N}$ (phosphonomethyl) glycine) 3 weeks before pre-treading measurements and hand-clipped at ground level 3 days before pre-treading measurements. Subplots with the $20 \mathrm{~mm}$ canopy height were clipped at approximately $25 \mathrm{~mm}, 3$ days before pretreading measurements were taken. Subplots with the $47 \mathrm{~mm}$ canopy height were fertilized with urea at $200 \mathrm{~kg} \mathrm{ha}^{-1}(96$ $\mathrm{kg} \mathrm{N} \mathrm{ha}{ }^{-1}$ ) 3 weeks before pre-treading measurements were taken. Before pretreading measurements were taken, one, 1 x $0.5-\mathrm{m}$ site with a moderate $\left(15\right.$ to $\left.18^{\circ}\right)$ slope within each $15 \times 3-\mathrm{m}$ subplot, was identified to measure the effects of canopy height and surface roughness on infiltration rate and sediment loss. To evaluate the effects of hill slope and canopy height on infiltration rate and sediment loss, $1 \mathrm{x}$ $0.5-\mathrm{m}$ sites with gentle $\left(8\right.$ to $14^{\circ}$ ) and moderately steep $\left(20\right.$ to $\left.25^{\circ}\right)$ slopes were identified within each subplot with a short or high canopy that were to be severely trodden.

Treading treatments were applied immediately after pre-treading measurements were taken. Plots with moderate or severe treading were established by slowly walking 4 or 8 mature cows (mean weight, 529 $\mathrm{kg}$ ), respectively, around the 15 x 9-m plots for $40 \mathrm{~min}$ to attempt to obtain uniform treading of each plot. Measurement sites were thus trodden to create approximately twice the number of hoof prints in the severe treading plots as those subjected to moderate treading. The range of hoof print damage caused by each treatment was visually representative of winter grazed pastures. Plots with the control treading treatment were not trodden by cattle and, therefore, represented longterm grazing by sheep only. Standing hoof pressure applied by cows, calculated from the cows' mean weight and the contact area of each hoof print, was estimated to be $195 \mathrm{kPa}$ compared to $80 \mathrm{kPa}$ reported for sheep (Willatt and Pullar 1983). These values, however, may underestimate hoof pressure by a walking animal by as much as $100 \%$ (Willatt and Pullar 1983).

\section{Measurements}

Sward canopy height at each site was determined from the mean of 25 'first hit' sward stick measurements pre-treading. Proportions of bare soil at each measurement site, defined as exposed soil with no litter, were estimated pre- and post-treading from overhead digital photographs taken with a Kodak DC 50 camera (Kodak Co., Rochester, NY) ${ }^{1}$ at a high-resolution setting. Images were cropped using Photoenhancer ${ }^{\odot}$ software (Kodak Co., Rochester, N.Y $)^{1}$, and hue and intensity thresholds for bare soil and green forage were established using the 'Define by Color' tool in Sigma ScanPro ${ }^{\odot}$ version 4 software (Jandel Scientific Software, San Rafael, Calif.) on portions of the pictures where only bare soil or green forage were present. The proportions of bare ground and green forage cover areas were calculated by dividing the number of pixels identified as bare or covered from the hue and intensity thresholds by the total number of pixels present in each picture. Proportions of bare ground calculated by this method were highly correlated $(\mathrm{r}=$ 0.91 ) to estimates made by counting 76 'first hit' pins at each site, using a contometer described below.

Infiltration rate (from the difference in rainfall and runoff) and sediment loss from each $0.5 \times 1.0-\mathrm{m}$ site within each canopy height, treading level, and slope treatment were determined with a rainfall simulator (Bowyer-Bower and Burt 1989) pre- and post-treading. Each simulator was positioned with the longer dimension running downhill. The distance from the base of the rainfall simulator to the soil surface ranged from approximately $0.6 \mathrm{~m}$ at the uphill end to approximately $1.0 \mathrm{~m}$ at the downhill end. A metal shield forced into the soil around the sites prevented surface flow into or out of the site. To collect surface runoff, a smooth soil face was cut across the downhill end of each site to a depth of approximately $10 \mathrm{~cm}$ and protected with Versi-foam ${ }^{(}$pre-treading and petroleum jelly post-treading. The collection tray was placed into the cut face approximately $5 \mathrm{~cm}$ from the soil surface, and collected water was transferred by hose to a 4-liter bottle placed approximately $0.6 \mathrm{~m}$ downhill. Mean simulated

${ }^{1}$ Reference to any commercial product does not imply an endorsement of the product by AgResearch or Iowa State University over any similar suitable product. 
rainfall rates during 90 min were $36.1 \pm 9$ liter $\mathrm{hr}^{-1}\left(7.22 \mathrm{~cm} \mathrm{~h}^{-1}\right)$. Raindrop speed ranged from 3.1 to $4.3 \mathrm{~m} \mathrm{~second}^{-1}$ (34 to $47 \%$ of terminal velocity) at the uphill and downhill ends of the simulator using a table in Laws (1941) at the rainfall rate and the height of simulator used. Volumes of water applied and runoff collected were recorded at 10-min intervals. The area to which water was applied and collected was adjusted by dividing the $0.5-\mathrm{m}^{2}$ area of the rainfall simulator by the cosine of the hill's slope. Water infiltration rate was calculated by subtracting the amount of water runoff by the amount of water applied during each 10-min increment. Steady state water infiltration rate was identified as the interval when incremental infiltration rates did not decrease and was achieved within $60 \mathrm{~min}$ in all cases. To determine sediment loss, six, 1-liter samples of runoff were taken and composited for the first $60 \mathrm{~min}$ of each rainfall simulation. Sediment concentration was determined by oven-drying duplicate $500-\mathrm{ml}$ subsamples at $105^{\circ} \mathrm{C}$ until dry. Sediment loss was calculated by multiplying sediment concentration by the water runoff rate for the first hour of each simulation.

Gravimetric soil moisture content was determined on duplicate samples collected at a depth of 0 to $7.5 \mathrm{~cm}$ from both sides of each site simultaneous to the determination of infiltration rates and sediment loss. Soil moisture was determined by ovendrying samples at $105^{\circ} \mathrm{C}$ for 48 hours.

Numbers of hoof prints and skids within each site were counted immediately after the treading event.

Surface roughness was quantified posttreading with a 38-pin contometer (Betteridge et al. 1999) with 25-mm spacing between pins along a $0.95-\mathrm{m}$ transect. To measure surface roughness across each $0.5 \times 1-\mathrm{m}$ site, a rectangular frame was constructed that enabled measurements to be taken on 21 parallel transects at $25-\mathrm{mm}$ intervals. Pin heights above the support bar of the contometer were measured using digital photographs cropped using Photoenhancer $^{\odot}$ software (Kodak Co., Rochester, N.Y.) ${ }^{1}$ and analyzed for length using the Longest Axis Length option in the measurement tool of Sigma ScanPro ${ }^{\odot}$ version 4 software (Jandel Scientific Software, San Rafael, Calif.) ${ }^{1}$. Measurements from the contometer were adjusted to be perpendicular to the horizontal to ensure pin heights were not confounded by land slope. This was achieved by adjusting for slopes of both the contometer and the land with the equation:
Standardized pin height, $\mathrm{cm}=\left(\mathrm{P}+\mathrm{L} / \mathrm{sin} \mathrm{A}_{\mathrm{c}}\right)-\left(\mathrm{L} * \cos \mathrm{A}_{\mathrm{c}}\right.$

$* \sin \mathrm{A}_{\mathrm{S}} / \cos \mathrm{A}_{\mathrm{S}}$

where:

$\mathrm{P}=$ pin height, $\mathrm{cm}$;

$\mathrm{L}=$ distance from the lower end of the contometer to the pin measured, $\mathrm{cm}$;

$\mathrm{A}_{\mathrm{c}}=$ angle from horizontal of contometer, degrees;

$A_{s}=$ angle from horizontal of soil surface, degrees.

Surface roughness was defined for each site as a roughness coefficient calculated as the standard deviation of difference of the standardized pin height in millimeters from the 4-cell moving average along the 21 contometer transects $(n=684)$ at each site. The 4-cell moving average was calculated as the mean of the 4 pins surrounding a given pin. The use of the moving average transformation was made to separate and remove the variance component caused by land contour from that of a treading-induced disturbance (Eltz and Norton 1997).

The 798 pin readings from each site also enabled a 3-dimensional surface contour graph to determine volumes of depressions or clumps. To include hill slope into the contour of the plot, pin height was only corrected for contometer slope with the equation:

Contour pin height,

$$
\mathrm{cm}=\mathrm{P} * \cos \mathrm{Ac}+\mathrm{L} * \sin \mathrm{A}_{\mathrm{c}}
$$

where:

$\mathrm{P}=$ pin height, $\mathrm{cm}$;

$\mathrm{L}=$ distance from the lower end of the contometer to the pin measured, $\mathrm{cm}$;

$\mathrm{A}_{\mathrm{c}}=$ angle from horizontal of contometer, degrees.

Contours were plotted on a contour graph at $15-\mathrm{mm}$ intervals using incremental colors with Sigma ScanPro $^{\odot}$ version 4 software (Jandel Scientific Software, San Rafael, Calif.) ${ }^{1}$. Depressions, representing detention storage volumes, and clumps were identified as completely enclosed objects on the graph with the same color line as an adjacent contour line below (depression) or above (clump) the object. Volumes of these objects were calculated from the area of each object plus any additional contour area within each object using the trace measurement option of Sigma ScanPro ${ }^{\odot}$ version 4 software (Jandel Scientific Software, San Rafael, Calif.) ${ }^{1}$ and multiplying this total area by $15 \mathrm{~mm}$. Total surface storage and clump volumes of each site were calculated as the sum of the respective volume measure- ments on each site divided by the plot area covered by the contometer.

\section{Statistical Analyses}

The effects of experimental treatments on canopy height, hoof prints or skids, roughness coefficient, detention storage volume, infiltration rate, and sediment loss were analyzed as a split plot model using General Linear Models (GLM) procedure (SAS 1988) with main effects of treading damage tested against the treading damage by block interaction and canopy height and/or hill slope tested against the error mean square. Post-treading soil water content, rainfall rate for each site, and the corresponding pre-treading independent variables were used as covariates, where appropriate, to standardize the data when testing post-treading independent variables. Stepwise multiple regressions were calculated to determine the dependent variables predicting post-treading steady state water infiltration rate, runoff sediment concentration, and total sediment loss from the independent variables of hill slope, canopy height, post-treading soil moisture, bare soil, hoof print and skid densities, detention storage volume, clump volume, and the roughness coefficient (SAS 1988). Variables were included in the model of the stepwise multiple regression only if they were significant at a probability level less than 0.15 .

\section{Results}

\section{Canopy Height and Cover}

Pre-treading canopy heights of moderate slope $\left(15\right.$ to $\left.18^{\circ}\right)$ sites were $6 \mathrm{~mm}$ on the denuded site and 20 and $47 \mathrm{~mm}(\mathrm{P}<0.01$, Table 1) on the other sites. These canopy heights corresponded to herbage least square mean masses of $-74,273$, and 922 $\mathrm{kg}$ dry matter ha ${ }^{-1}$, respectively, at about a nominal clipping height of $10 \mathrm{~mm}$.

The proportion of bare ground was far greater $(\mathrm{P}<0.01)$ on denuded sites than on sites with greater canopy heights (Table 2). While the mean proportion of bare ground of denuded sites pre- and post-treading was $80.4 \%$, the mean proportion of bare ground in sites with as little as $20-\mathrm{mm}$ canopy was only $10.8 \%$. The proportion of bare ground was greater $(\mathrm{P}<$ 0.01 ) after treading treatments were applied with mean increases of $0,8.0$, and 17.6 percentage units on sites with no, moderate, and severe cattle treading. Because the mean increases in the proportions of bare ground in sites with the denuded, $20 \mathrm{~mm}$ and $47 \mathrm{~mm}$ canopy 
Table 1. Least square means of effects of treading damage and canopy height on soil characteristics and hydraulic properties.

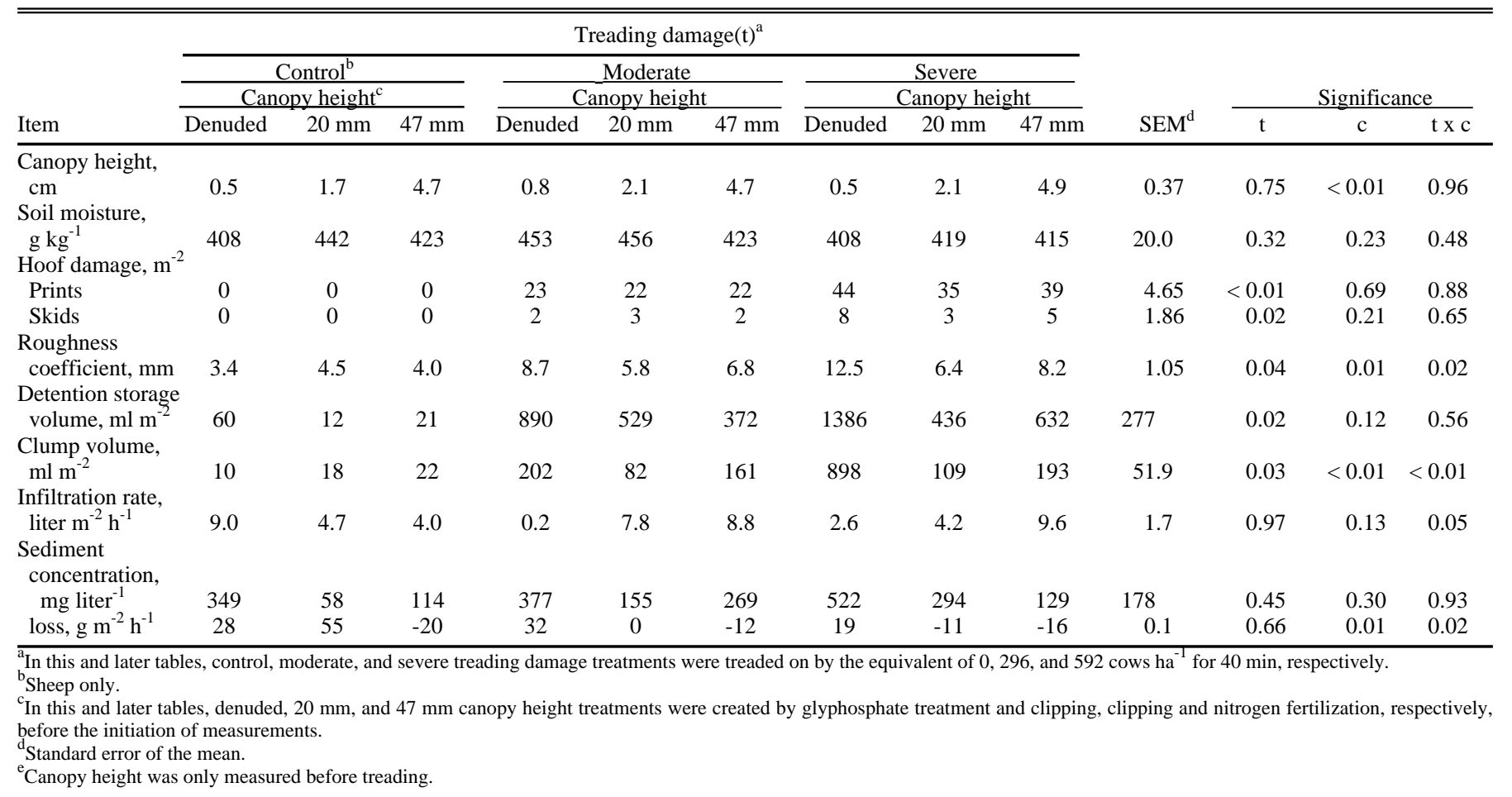

heights were 5,10 , and 11 percentage units $(\mathrm{P}<0.05)$, it seems that sites with the higher canopies had a greater potential for loss of ground cover.

Soil moisture contents at the time of rainfall simulations did not differ between canopy cover or treading treatment (Table 1).

\section{Soil Surface Damage}

Treading at the equivalent of 296 and 592 cows ha- 1 for 40 min resulted in a mean of 22 and 39 hoof prints $\mathrm{m}^{-2}(\mathrm{P}<$ $0.01)$ and 2 and 5 hoof skids $\mathrm{m}^{-2}(\mathrm{P}=0.02$, Table 1). Similarly, roughness coefficients, detention storage volume, and clump volume increased $(\mathrm{P}<0.05)$ as stocking density increased. Because roughness coefficients of sites that were trodden at moderate and severe levels were 178 and $226 \%$ of those untrodden sites and roughness coefficients were well correlated with hoof print density ( $\mathrm{r}=$ 0.75 ), it seems that the roughness coefficient very effectively describes treading damage treatments. Detention storage volume $(\mathrm{r}=0.67)$ and clump volume $(\mathrm{r}=$ 0.61 ) also were correlated with hoof print density, but not as strongly as the roughness coefficient. Because the detention storage and clump volumes were calculated volumes with a degree of extrapolation, whereas the roughness coefficient was calculated from point values, the closer relationship of hoof print density with the roughness coefficient than those of hoof print density with detention storage volume or clump volume is not surprising.

Canopy heights did not affect the density of hoof prints or skids. However, the roughness coefficient and clump volume were greater $(\mathrm{P}<0.01)$ on denuded sites, particularly as the degree of treading increased (treading damage $\mathrm{x}$ canopy height, $\mathrm{P}<0.05)$. This result indicates that while the presence of forage on the ground does not prevent hoof prints or skids from occurring, it apparently minimizes the depth to which hooves sink into the soil, effectively changing the ability of the soil to deform at a moderate moisture content. Similar to the roughness coefficient and

clump volume, detention storage volume tended $(\mathrm{P}=0.12)$ to be greater on sites with shorter canopies. The greater clump volumes on the severely trodden denuded sites compared to those on the severely trodden sites with canopy heights of 20 and $47 \mathrm{~mm}$, but not on the moderately trodden sites at all canopy heights, suggests a threshold of treading intensity on denuded land, above which the deformation process is activated but below which compaction only is present. Thus, in New Zealand hill country pastures with the high tiller density of the common sodgrass species, a mean canopy height as short as $20 \mathrm{~mm}$ seems to be sufficient to minimize the effects of treading on the soil's rough-

Table 2. Least square means of effects of treading and canopy height treatments on the proportion of bare ground before and after treading.

\begin{tabular}{|c|c|c|c|c|c|c|}
\hline \multirow[b]{3}{*}{$\begin{array}{l}\text { Canopy height } \\
\text { (c) }\end{array}$} & \multicolumn{6}{|c|}{ Treading damage } \\
\hline & \multicolumn{2}{|c|}{ Control } & \multicolumn{2}{|c|}{ Moderate } & \multicolumn{2}{|c|}{ Severe } \\
\hline & Pre-tread & Post-tread & Pre-tread & Post-tread & Pre-tread & Post-tread \\
\hline & \multicolumn{6}{|c|}{ 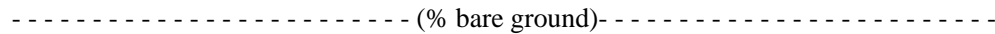 } \\
\hline Denuded & 78.1 & 78.1 & 78.8 & 82.8 & 77.0 & 87.8 \\
\hline $20 \mathrm{~mm}$ & 10.7 & 10.7 & 3.3 & 9.9 & 3.6 & 26.7 \\
\hline $47 \mathrm{~mm}$ & 0.4 & 0.4 & 0.1 & 13.5 & 0.2 & 19.3 \\
\hline $\mathrm{SEM}^{\mathrm{a}}$ & 2.24 & & & & & \\
\hline Significance & Main effects & \multicolumn{5}{|c|}{ Change by treading } \\
\hline $\mathrm{T}$ & 0.22 & $<0.01$ & & & & \\
\hline $\mathrm{C}$ & $<0.01$ & 0.05 & & & & \\
\hline $\mathrm{t} \times \mathrm{c}$ & 0.85 & 0.11 & & & & \\
\hline
\end{tabular}

${ }^{\mathrm{a}}$ Standard error of the mean. 
ness coefficient and detention storage volume and effectively raise the moisture content at which soil will deform. Volumetric soil moisture contents of the soil at all sites were slightly below the lower plastic limit $\left(46 \% \mathrm{~m}^{3} \mathrm{~m}^{-3}\right)$ of soils at this site prior to treading. At this volumetric soil moisture content, soils should have compressed when trodden rather than deformed (Betteridge et al. 1999), although the validity of the plastic limit value may be questioned in soils with intact plant roots.

Except where there was no cattle treading, infiltration rate was lower on denuded sites (treading damage $\mathrm{x}$ canopy, $\mathrm{P}=$ $0.05)$. The reduction in infiltration rate was associated with those sites with greater roughness, detention storage volume, and clump volume caused by hoof action, which is consistent with the hypothesis that damage to soil surface affects surface infiltration properties and the functional characteristics of the surface and soil pores immediately below the soil surface. The presence of a canopy reduces stock treading damage to the soil surface, as measured by lower roughness coefficients, detention storage volumes, and clump volumes resulting in less smearing and blocking of surface pores and possibly less compaction of subsurface macropores preserving the surface infiltration characteristics of the soil. Thus, during a grazing event, surface infiltration rate will be more prone to negative impacts as animals consume the forage to a height less than $20 \mathrm{~mm}$.

\section{Sediment Loss}

Mean sediment concentration was extremely variable between treatments and did not differ between treading damage or canopy height treatments. Similar to sediment concentration, sediment loss was not affected by the amount of treading damage. Because of the reduced infiltration rate and, therefore, greater runoff, sediment loss was greater as the canopy became shorter. The exception to this pattern was that the highest sediment loss occurred on the untrodden, $20 \mathrm{~mm}$ canopy height treatment, which may have been caused by soil dislodged from the cut soil face above the runoff collector that grossly inflated the estimate of sediment concentration in one block. For the 2 trodden treatments, the difference in sediment loss was much greater between the denuded and $20 \mathrm{~mm}$ canopy heights than between the 20 and $47 \mathrm{~mm}$ canopy height treatments. Therefore, similar to the measurements of surface roughness, overland sediment loss is minimized in New Zealand hill land pastures with common forage species at canopy heights as low as 20 $\mathrm{mm}$. While there was no difference in sediment loss between sites with a $47 \mathrm{~mm}$ canopy height subjected to the 3 levels of treading damage, sediment loss decreased with increasing treading damage on sites with the denuded and $20 \mathrm{~mm}$ canopy height treatments (treading damage $\mathrm{x}$ canopy height, $\mathrm{P}=0.02$ ). This difference may have resulted from the sites with little or moderate treading damage having the longer slope lengths between obstructions, over which water gains erosive energy (Lal and Elliott 1994) and having less surface depressions into which sediment can be trapped. While treading increases the number and area of clumps from which sediment may erode, it also reduces slope lengths and increases the volumes of detention storage that can detain detached soil particles. Increased roughness of the soil surface and greater canopy covers are major contributors to reducing wind erosion in cropped lands (Skidmore et al. 1994). With the exception of the extremely high sediment loss from the untrod 20 $\mathrm{mm}$ canopy height treatment, there was a clear trend for sediment loss declining with increasing canopy height. With treading damage, some disturbance of the soil resulted in an increase in sediment loss, but further damage saw a reduction in soil loss. In stepwise multiple regression analysis, the proportion of bare soil (BS), the average slope (AS) within the range of 15 to $18^{\circ}$, and the roughness coefficient (RC) were selected as significant variables to predict sediment concentration by the equation:

Sediment concentration,

mg liter-1=3.5BS + 176AS -

32RC - $2594\left(r^{2}=0.67\right)$.

In stepwise multiple regressions predicting sediment loss, the proportion of bare soil (BS) and the average slope (AS) within the range of 15 to $18^{\circ}$ were selected as significant variables by the equation:

$$
\begin{aligned}
& \text { Sediment loss, } \\
& \operatorname{gm~m}^{-2} \text { hour }^{-1}=0.1 \mathrm{BS}+2.6 \mathrm{AS} \\
& -38.9\left(\mathrm{r}^{2}=0.63\right) .
\end{aligned}
$$

\section{Slope and Canopy Cover}

As designed, canopy height was greater $(\mathrm{P}<0.01)$ in sites with the $47 \mathrm{~mm}$ canopy height than in those that were denuded (Table 3). Canopy height, however, did not differ between sites with different slopes. The proportion of bare ground was greater $(P=0.03)$ in denuded sites than in those with the $47 \mathrm{~mm}$ canopies. Canopy height alone did not affect the density of hoof prints or slips, roughness coefficient, detention surface storage volume, or clump volume. However, roughness coefficients and clump volumes were greater $(\mathrm{P}<0.05)$ on the denuded sites, particularly at the medium slope (canopy height $\mathrm{x}$ slope, $\mathrm{P}<0.05$ ). Slope, however, did not significantly affect the density of hoof prints or skids or detention storage volume. While in the comparison of canopy height and treading damage discussed above, removal of canopy led to greater soil surface damage when experimental treading treatments were applied, this was only seen on the medium slope in the second trial. The lack of greater damage to the denuded sites with the high and low slopes may be related to uneven damage applied as cattle were moved around these subplots, although there were no significant differences in the density of hoof prints and skids. As in the previous analysis, neither infiltration rate nor sediment concentration was impacted by plant cover, and slope had no effect on infiltration rate, sediment concentration, or sediment loss.

In stepwise multiple regressions using data from the canopy height and slope evaluation, the densities of hoof skids (HS), clump volume (CV), hill slope (AS), and canopy height $(\mathrm{CH})$ were selected as significant variables to predict sediment concentration (Eq. 5), hill slope (AS), density of hoof prints (HP), density of hoof skids (HS), and clump volume (CV) to predict sediment loss (Eq. 6), and density of hoof prints (HP) and roughness coefficient (RC) to predict infiltration rate (Eq. 7) by the equations:

Sediment concentration, mg liter ${ }^{-1}=28.0 \mathrm{HS}+0.16 \mathrm{CV}-$

7.0AS - 27.5CH -251.6 $\left(r^{2}=0.97\right)$;

Sediment loss,

$\mathrm{g} \mathrm{m}^{-2}$ hour $^{-1}=0.14 \mathrm{AS}-0.14 \mathrm{HP}$

$+0.4 \mathrm{HS}+0.02 \mathrm{CV}+2.76$

$\left(r^{2}=0.96\right)$;

and Infiltration rate,

liter $\mathrm{m}^{-2}$ hour $^{-1}=0.26 \mathrm{HP}-1.53 \mathrm{RC}$

$+9.27\left(r^{2}=0.53\right)$.

\section{Discussion}

Previous studies have shown that the relationship between water infiltration and sediment loss is complex and dependent on soil, vegetation, and grazing management (Thurow et al. 1986, Warren et al. 1986a, 1986b, 1986c, 1986d). In this study, treading resulted in an increased roughness coefficient, detention storage volume, and clump volume in conjunction 
Table 3. Least square means of the effects of canopy height and hill slope on soil characteristics and hydrologic properties.

\begin{tabular}{|c|c|c|c|c|c|c|c|c|c|c|}
\hline \multirow[b]{4}{*}{ Item } & \multicolumn{6}{|c|}{ Canopy height (c) } & \multirow[b]{4}{*}{$\mathrm{SEM}^{\mathrm{b}}$} & \multirow{2}{*}{\multicolumn{3}{|c|}{ Significance }} \\
\hline & \multirow{2}{*}{\multicolumn{3}{|c|}{$\frac{\text { Denuded }}{\text { Hill slope }(\mathrm{s})^{\mathrm{a}}}$}} & \multirow{2}{*}{\multicolumn{3}{|c|}{$\begin{array}{l}47 \mathrm{~mm} \\
\text { Hill Slope }\end{array}$}} & & & & \\
\hline & & & & & & & & \multirow[b]{2}{*}{$\mathrm{c}$} & \multirow[b]{2}{*}{ s } & \multirow[b]{2}{*}{$\mathrm{cxs}$} \\
\hline & Low & Medium & High & Low & Medium & High & & & & \\
\hline$\overline{\text { Canopy height, } \mathrm{mm}^{\mathrm{c}}}$ & 5.6 & 4.7 & 10.3 & 31.0 & 51.1 & 49.5 & 35.5 & $<0.01$ & 0.22 & 0.22 \\
\hline $\begin{array}{l}\text { Soil moisture, } \\
\mathrm{g} \mathrm{kg}^{-1, \mathrm{e}} \\
\text { Hoof damage, } \mathrm{m}^{-2, \mathrm{~d}}\end{array}$ & 411 & 412 & 401 & 440 & 407 & 318 & 14.0 & 0.44 & 0.14 & 0.26 \\
\hline Prints & 35 & 43 & 38 & 28 & 40 & 29 & 9.4 & 0.34 & 0.41 & 0.92 \\
\hline Skids & 2 & 8 & 3 & 3 & 5 & 4 & 4.5 & 0.83 & 0.54 & 0.79 \\
\hline Roughness coefficient, $\mathrm{mm}^{\mathrm{d}}$ & 6.6 & 12.4 & 7.5 & 8.0 & 7.9 & 6.5 & 0.56 & 0.55 & 0.02 & 0.05 \\
\hline Detention storage volume, $\mathrm{ml} \mathrm{m}^{-2, \mathrm{~d}}$ & 758 & 1396 & 144 & 1175 & 552 & 230 & 315 & 0.86 & 0.11 & 0.18 \\
\hline $\begin{array}{l}\text { Clump volume, } \\
\mathrm{ml} \mathrm{m}^{-2, \mathrm{~d}}\end{array}$ & 235 & 898 & 265 & 372 & 185 & 7 & 111 & 0.25 & 0.03 & 0.05 \\
\hline Bare ground, $\%{ }^{\mathrm{e}}$ & 80.5 & 87.9 & 84.3 & 24.7 & 18.3 & 10.7 & 2.5 & 0.03 & 0.29 & 0.16 \\
\hline $\begin{array}{l}\text { Infiltration rate, liter } \\
\mathrm{m}^{-2} \mathrm{~h}^{-1, \mathrm{e}}\end{array}$ & 6.9 & 0.9 & 8.5 & 2.0 & 8.3 & 9.4 & 2.73 & 0.65 & 0.45 & 0.34 \\
\hline $\begin{array}{l}\text { Sediment, } \\
\text { concentration, } \\
\text { mg liter } \\
\text { loss, } \mathrm{g} \mathrm{m}^{-2} \mathrm{~h}^{-1}\end{array}$ & $\begin{array}{c}234 \\
3.8\end{array}$ & $\begin{array}{l}490 \\
18.0\end{array}$ & $\begin{array}{l}186 \\
5.6\end{array}$ & $\begin{array}{l}228 \\
9.0\end{array}$ & $\begin{array}{l}154 \\
4.7\end{array}$ & $\begin{array}{l}65 \\
2.2\end{array}$ & $\begin{array}{l}103 \\
2.4\end{array}$ & $\begin{array}{l}0.12 \\
0.16\end{array}$ & $\begin{array}{l}0.34 \\
0.12\end{array}$ & $\begin{array}{l}0.49 \\
0.12\end{array}$ \\
\hline
\end{tabular}

with greater density of hoof prints and skids. The presence of a canopy as short as $20 \mathrm{~mm}$ minimized the change in soil microrelief, measured as roughness coefficient, detention storage volume, clump volume, or bare ground and reduced sediment loss. The very dense vegetative cover of the sodgrass species common to the New Zealand hill country probably compensates for the lack of canopy height in reducing water erosion, compared with less dense but taller canopies found in other environments. Nevertheless, increasing the canopy height to $47 \mathrm{~mm}$ gave even greater protection against sediment loss.

In Texas rangeland containing oak motte, bunchgrass, or sodgrass vegetation types and grazed with 3 different systems, Thurow et al. (1986) found that total vegetative cover was positively and soil bulk density was negatively related to water infiltration rate, and total aboveground biomass and bunchgrass cover were positively related to sediment production. In similar pastures grazed with an intensive rotational stocking system at 3 different stocking rates, it was found that vegetative biomass and bare ground percentage were significantly correlated with water infiltration rate and sediment production (Warren et al. 1986c).

The observation that minor surface damage in the absence of a vegetative canopy results in more sediment loss than severe damage is consistent with guidelines for reducing soil loss from wind and water erosion from cropland. A shorter field length reduces the erosiveness of wind (Skidmore et al. 1994) or water (Lal and Elliot 1994), and the consequent rougher surface creates turbulence that reduces the speed of air or water. A rougher surface also entraps moving particles, which are then unable to contribute to abrasive erosion (Lal and Elliot 1994). Vegetative cover dissipates the energy of falling raindrops and the grass tillers and rooted stolons of clover act to reduce the "field length" over which water can run uninterrupted.

In this experiment, the highly variable infiltration rate tended to mask patterns related to cover and roughness. In the untrodden sites, infiltration rate was slower in the sites with 20 and $47 \mathrm{~mm}$ canopy heights, possibly because the vegetative cover formed a protective layer, reducing effective rainfall at ground level. In the moderately and severely damaged sites with 20 and $47 \mathrm{~mm}$ canopies, infiltration rates were faster than denuded sites although the trodden denuded sites had greater roughness coefficients and tended to have greater detention storage detention volumes. Thus, the slower infiltration rates in trodden denuded sites may have been caused by fine sediments generated during treading and dislodged by water that may have sealed the infiltration sites in the soil surface. Thurow et al. (1986) observed lower water infiltration rates and greater sediment loss from dense sodgrass than from the more open bunchgrass or oak motte vegetations. Whereas the proportion of vegetative cover including litter was between 45 and $70 \%$ on the sodgrass sites used by Thurow et al. (1986), the mean postgrazing vegetative covers of the sites with medium and high canopy heights in the present experiment were 84 and $89 \%$.

In spite of the large effects of 'nominal' canopy height on the bare ground percentage, roughness coefficient, and sediment loss, 'actual' canopy height was not related to infiltration rate or sediment loss. The percentage of bare ground and slope (within the 14 to $18^{\circ}$ range only) explained $63 \%$ of variation in sediment loss and with the roughness coefficient accounted for $67 \%$ of variation in sediment concentration. Warren et al. (1986b) confirmed the importance of vegetative cover as they found that animal trampling on sites devoid of vegetation on dry and moist soils resulted in infiltration rate and sediment loss being highly correlated to soil bulk density and microrelief. The positive relationship between bare ground and sediment loss in our first trial likely was caused by both reduced interception of rainfall by plant material and the reduced obstruction of sediment transport. Because of the high density of tillers and stolons, sodgrass species in New Zealand hill country pastures likely require less herbage biomass to achieve the same level of protection against rain afforded by the more open bunchgrass species present in Texas rangeland.

When comparing the effects of canopy height and slope of soil hydrological properties, sediment loss increased with 
increasing slope, hoof skid density, and clump volume. Surprisingly, the proportion of bare ground was not a significant factor in the prediction of infiltration rate or sediment loss across a greater range of slopes $\left(8\right.$ to $25^{\circ}$ ) in the second trial despite proportions of bare ground of 84 and $18 \%$ on the denuded and $47 \mathrm{~mm}$ canopy height sites, respectively. The lack of differences in infiltration rate and sediment loss may have been caused by collecting these data from only severely damaged sites on which variation in sediment loss was low. The negative impact of slope on sediment concentration probably reflects the shorter field lengths between obstructions that reduce water's erosiveness on steeply sloping sites compared to gently sloping ground. At a given plant density, taller canopies negatively impact sediment concentration by reducing the energy of impacting raindrops.

Whereas a rough surface reduces sediment loss by trapping more sediment and reducing water's erosivity, it reduces infiltration rate, probably because of the blocking of surface micropores by trapped fine sediments. The positive relationship between hoof print density and infiltration rate is difficult to explain, as hoof prints are likely associated with either compacted soil under the print when the soil is at a moisture content within the plastic range, or a loss of pore continuity if the soil was deformed by treading in poorly drained hill country soils in New Zealand (Betteridge et al. 1999). While the increasing infiltration rate with hoof print density may have been associated with greater retention volumes, infiltration rates in our study were determined after steady state infiltration was achieved and, therefore, retention structures should have been filled.

Increasing soil microrelief has been negatively related to sediment loss from Texas rangeland (Warren et al. 1986a, 1986b, 1986d, Thurow et al. 1988a). While the increased microrelief in the Texas study was caused primarily by the presence of plant material that would increase water and sediment retention on a low slope, the increased microrelief in the present study occurred primarily in the absence of plant material and was related to hoof damage.

\section{Conclusion}

Infiltration rate of soil under $\mathrm{New}$ Zealand hill country pastures will be reduced by treading wet pastures, particular ly if the postgrazing canopy height is short and the stocking rate is high. A canopy height of only $20 \mathrm{~mm}$ is high enough to limit the effects of a short period of treading damage. The lack of a relationship between sediment loss and roughness coefficient supports the finding that soils receiving severe damage in the presence of an adequate canopy are less prone to incipient sediment loss than is the case of less severely damaged soils devoid of vegetation.

\section{Literature Cited}

Betteridge, K., A.D. Mackay, D.J. Barker, T.G. Shepherd, P.J. Budding, B.P. Devantier, and D.A. Costall. 1999. Effect of cattle and sheep treading on surface configuration of a sedimentary hill soil. Aust. J. Soil Res. 37:743-760.

Bowyer-Bower, T.A.S., and T.P. Burt. 1989. Rainfall simulators for investigating soil response to rainfall. Soil Tech. 2:1-16.

Eltz, F.L.F. and L.D. Norton. 1997. Surface roughness changes as affected by rainfall erosivity, tillage, and canopy cover. J. Soil Sci. 61:1746-1755.

Lal, R. and W. Elliot. 1994. Erodibility and erosivity pp. 181-208. In: Soil Erosion Research Methods ( $2^{\text {nd }}$ Ed.) R. Lal (ed.) Soil and Water Conservation Society, Ankeny, Ia.

Lambert, M.G., D.A. Clark, D.A. Grant, and D.A. Costall. 1983. Influence of fertiliser and grazing management on North Island moist hill country. I. Herbage accumulation. New Zealand J. of Agr. Res. 26:95-108.

Lambrechtsen, N.C. 1972. "What grass is that?" New Zealand Department of Scientific Industrial Research Information Series 87. pp. 136. DSIR, Wellington, NZ.

Laws, J.O. 1941. Measurements of the fallvelocity of water-drops and raindrops. Trans. Amer. Geophys. Union. 22:709-721.

SAS. 1988. SAS/STAT User's Guide-Release 6.03 edition, and SAS Procedures GuideRelease 6.03 edition. SAS Inst., Cary, N.C.

Sheath, G.W. and C.J. Boom. 1997. Impact of cattle grazing systems on treading damage and forage supply. Proc. New Zealand Grassl. Assoc. 59:87-92.

Skidmore, E.L., L.J. Hagen, A.A. Durar, D.W. Fryrear, K.N. Potter, L.E. Wagner, and T.M. Zoebeck. 1994. Methods for investigating basic processes and conditions affecting wind erosion. pp. 295-330. In: Soil Erosion Research Methods ( $2^{\text {nd }} E d$.) R. Lal (ed.) Soil and Water Cons. Soc., Ankeny, Ia.

Thurow, T.L., W.H. Blackburn, and C.A. Taylor, Jr. 1986. Hydrologic characteristics of vegetation types as affected by livestock grazing systems, Edwards Plateau, Texas. J. Range Manage. 39:505-509.

Thurow, T.L., W.H. Blackburn, and C.A. Taylor, Jr. 1988a. Infiltration and interrill erosion responses to selected livestock grazing strategies, Edwards Plateau, Texas. J. Range Manage. 41:296-302.
Thurow, T.L., W.H. Blackburn, and C.A. Taylor, Jr. 1988b. Some vegetation responses to selected livestock grazing strategies. J. Range Manage. 41:108-114.

Voorhies, W.B., J.F. Johnson, G.W. Randall, and W.W. Nelson. 1989. Corn growth and yield as affected by surface and subsoil compaction. Agron. J. 81:294-302.

Warren, S.D., W.H. Blackburn, and C.A. Taylor, Jr. 1986a. Effects of season and stage of rotation cycle on hydrologic condition of rangeland under intensive rotation grazing. J. Range Manage. 39:486-491.

Warren, S.D., W.H. Blackburn, and C.A. Taylor, Jr. 1986b. Soil hydrologic response to number of pastures and stocking density under intensive rotation grazing. J. Range Manage. 39:500-504.

Warren, S.D., M.B. Nevill, W.H. Blackburn, and N.E. Garza. 1986c. Soil response to trampling under intensive rotation grazing. J. Soil Sci. 50:1336-1341.

Warren, S.D., T.L. Thurow, W.H. Blackburn, and N.E. Garza. 1986d. The influence of livestock trampling under intensive rotation grazing on soil hydrologic characteristics. J. Range Manage. 39:491-495.

Willatt, S.T. and D.M. Pullar. 1983. Changes in soil physical properties under grazed pastures. Aust. J. Soil Res. 22:343-348. 